\title{
Journey of Leukoplakia So Far - An Insight on Shortcomings of Definitions and Classifications
}

\author{
Priyanka Kardam ${ }^{1 *}$, Shweta Rehani ${ }^{1}$, Monica Mehendiratta ${ }^{2}$, Khushboo Sahay $^{1}$, Yulia Mathias ${ }^{1}$ \\ and Rashi Sharma ${ }^{1}$ \\ ${ }^{1}$ Department of Oral Pathology \& Microbiology, Sudha Rustagi College of Dental Sciences and Research, Kheri More, Village Bhopani, \\ Faridabad - 121002, Haryana, India \\ ${ }^{2}$ Department of Oral Pathology \& Microbiology, ITS Dental College, Greater Noida, Uttar Pradesh 201308, India
}

Received: March 26, 2015; Accepted: May 20, 2015; Published: June 05, 2015

*Corresponding author: Dr. Priyanka Kardam, D-81, Ground Floor, Saket, New Delhi -110017India, Tel: 09717102171, Email: priyankakardam@gmail.com

\begin{abstract}
Leukoplakia is one of the most frequently encountered white lesions by the clinicians. The definitions and terminologies associated with leukoplakia have been proposed by various authors. Also, various attempts have been made to clinically and histopathologically grade leukoplakia by evaluating different criteria.

Although there are numerous reviews that have discussed the definitions and classifications of leukoplakia, none has attempted to provide a clear visualization of the shortcomings associated with each definition and classification. Hence, this review article is an attempt to highlight the main points as well as shortcomings in terminology, definitions, clinical classifications and histopathologic gradings which have been associated with leukoplakia till date.
\end{abstract} Grading

Keywords: Leukoplakia; Dysplasia; Definitions; Classifications;

\section{Introduction}

The term "leuko" refers to white and "plakia" signifies a plaque/patch. Hence, the literal meaning of the term leukoplakia is a "white plaque". More than any other oral disease, leukoplakia has suffered from an excess of diagnostic terms and definitions; at least 75 have been used thus far. This has led to such mystification that many clinicians refuse to use any term beyond "white patch" [1]. The first recorded white oral plaque/patch was an "ichthyosis" reported in 1818 by Alibert of Paris [2].

Although innumerous definitions and classifications have been devised, still there is a lack of consensus. The aim of this paper is to enlighten the highlights and shortcomings of these definitions and classifications. The knowledge and understanding of all the terminologies and classifications along with their shortcomings will provide a better insight for evaluating their appropriateness and comprehensiveness.

\section{Terminologies and definitions}

The first definitive terminology associated with leukoplakia was given by Schwimmer in 1877 [3]. Since then, numerous changes have been introduced by authors pertaining to size, etiology, exclusion of other lesions and potential for malignant transformation. The highlights, new points and shortcomings associated with each terminology have been consolidated in Table 1 [4-10].

\section{Clinical classifications}

Leukoplakia is one of the most commonly encountered white lesions by the clinicians and still holds an enigma around itself. Proper identification of the type of leukoplakia holds the key to successful treatment of the lesion. Hence, it is important for the clinician to recognize the type of leukoplakia as it can help in planning the treatment and also in predicting the malignant potential of the lesion [11].

Till date, numerous classifications for leukoplakia have been introduced based on criteria such as etiology, appearance, size and presence or absence of dysplastic features. Some authors have even commented, the clinical appearance of leukoplakia can be used to suspect the possibility of dysplasia being present in a lesion. Pindborg, et al. [12] confirmed that speckled leukoplakia was often associated with epithelial dysplasia or carcinoma as compared to homogenous leukoplakia. Sugar and Banoczy [13] in their three tiered clinical classification of 1969, reported that leukoplakia erosiva and leukoplakia verrucosa were more often associated with epithelial dysplasia than leukoplakia simplex. However, the clinical appearance cannot be confirmatively associated with presence or absence of dysplastic features. Various clinical classifications used for leukoplakia and their basis have been consolidated in Table 2 [14-17].

\section{Histopathologic grading}

Although leukoplakia is a pure clinical term and the lesion has no specific histology i.e. it may or may not demonstrate dysplasia. However for the purpose of histopathologic reporting, the term "dysplasia" has been used [18]. Various authors have proposed grading systems for leukoplakia, but each system has its own shortcomings. The highlights, new points and shortcomings of these grading systems have been consolidated in Table 3 [19-34]. 
Table 1: Terminologies and definitions associated with leukoplakia.

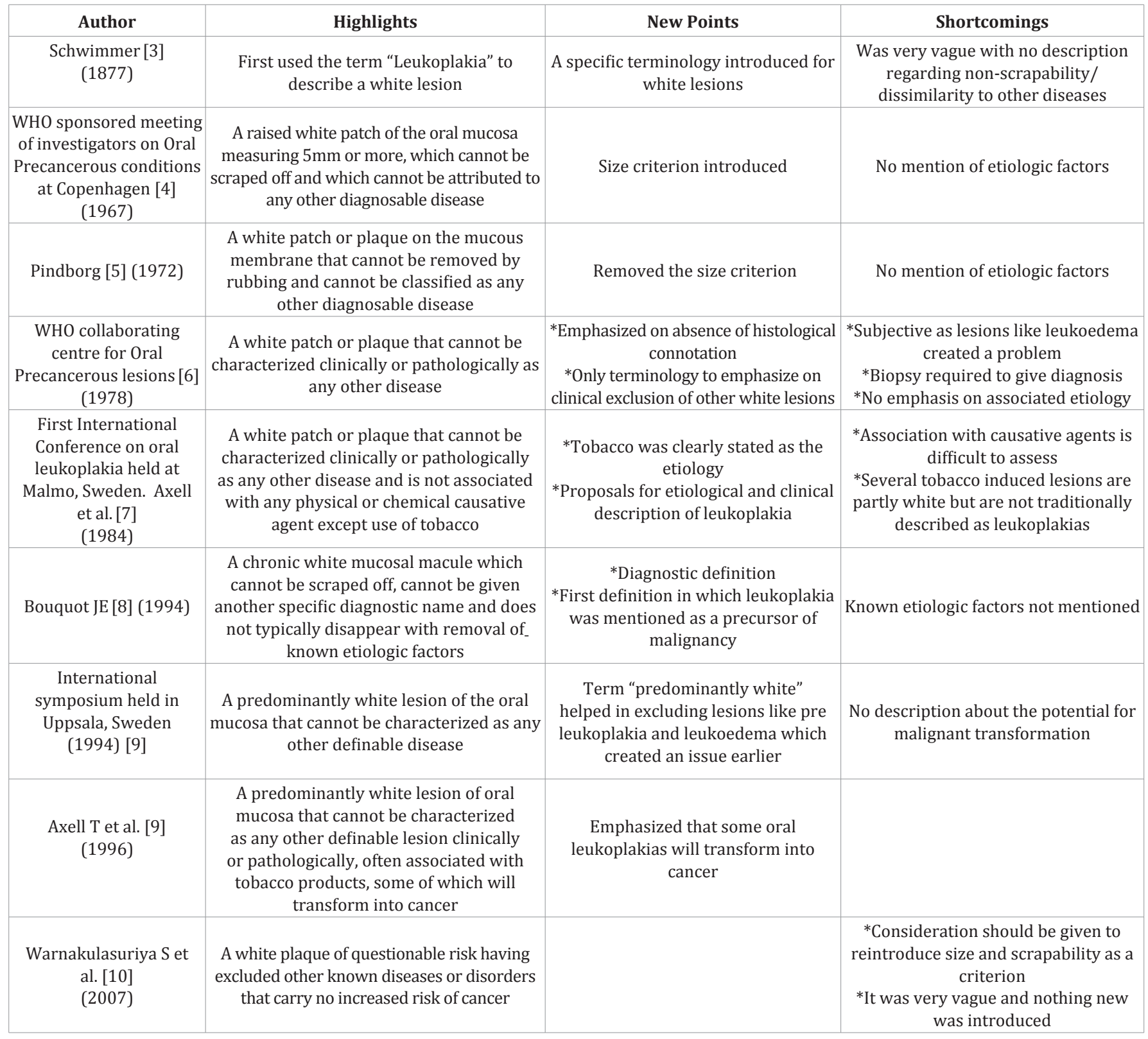

Table 2: Clinical classifications of leukoplakia.

\begin{tabular}{|c|c|c|c|}
\hline Author & Based On & Clinical Types & Remarks \\
\hline $\begin{array}{l}\text { Mehta et al. [14] } \\
\text { (1971) }\end{array}$ & $\begin{array}{c}\text { Clinical } \\
\text { appearance }\end{array}$ & $\begin{array}{l}\text { *Homogeneous - A raised plaque of variable size which is predominantly white but can } \\
\text { be grayish or yellow } \\
\text { *Ulcerated - Red/yellowish area surrounded by white patches which appears like an ulcer } \\
\text { *Nodular - A white patch on an erythematous base }\end{array}$ & $\begin{array}{l}\text { * It was the first attempt } \\
\text { to clinically categorize } \\
\text { leukoplakia } \\
\text { * It was clinically } \\
\text { applicable }\end{array}$ \\
\hline $\begin{array}{c}\text { Pindborg et al. [5] } \\
\text { (1972) }\end{array}$ & $\begin{array}{c}\text { Clinical } \\
\text { appearance }\end{array}$ & $\begin{array}{l}\text { *Ebbing tide - Appears like indulations left on sand by an ebbing tide. Especially occurs } \\
\text { on floor of the mouth } \\
\text { *Others- All other types of appearances were grouped together }\end{array}$ & $\begin{array}{l}\text { *Inconclusive } \\
\text { *Not commonly used }\end{array}$ \\
\hline $\begin{array}{c}\text { Amagasa et al. } \\
\text { [15] (1977) }\end{array}$ & $\begin{array}{c}\text { Clinical } \\
\text { appearance }\end{array}$ & $\begin{array}{l}\text { *Type 1- Flat white patch/plaque without red components } \\
\text { *Type 2- Flat white patch/plaque with erosion or red components } \\
\text { *Type 3- Slightly raised or elevated white patch/plaque } \\
\text { *Type 4- Markedly raised or elevated white patch/plaque }\end{array}$ & $\begin{array}{l}\text { Introduced the criteria } \\
\text { of being flat or raised }\end{array}$ \\
\hline
\end{tabular}




\begin{tabular}{|c|c|c|c|}
\hline $\begin{array}{l}\text { Banoczy J [13] } \\
\text { (1982) }\end{array}$ & $\begin{array}{l}\text { Clinical } \\
\text { appearance }\end{array}$ & $\begin{array}{l}\text { *Leukoplakia Simplex - White homogeneous keratinized lesion, slightly elevated } \\
\text { *Leukoplakia verrucosa - White verrucous lesion with wrinkled surface } \\
\text { *Leukoplakia erosiva - White lesion with erythematous, erosion, fissures }\end{array}$ & $\begin{array}{l}\text { For the first time } \\
\text { verrucous lesions were } \\
\text { mentioned separately }\end{array}$ \\
\hline $\begin{array}{l}\text { Axell et al. [9] } \\
\text { (1984) }\end{array}$ & Etiology & $\begin{array}{l}\text { *Idiopathic - Etiology unknown } \\
\text { *Tobacco associated leukoplakia - Caused by tobacco }\end{array}$ & $\begin{array}{l}\text { It was difficult to apply } \\
\text { clinically }\end{array}$ \\
\hline $\begin{array}{l}\text { International } \\
\text { symposium } \\
\text { held in Uppsala, } \\
\text { Sweden [9] } \\
\quad \text { (1994) }\end{array}$ & $\begin{array}{l}\text { Clinical } \\
\text { appearance }\end{array}$ & $\begin{array}{l}\text { *Homogenous - Predominantly white with cracked/wrinkled/smooth surface but a } \\
\text { consistent texture throughout. } \\
{ }^{*} \text { Non-homogenous Leukoplakia - } \\
\text { Erythroleukoplakias - Red and white lesion } \\
\text { Nodular - slightly raised, rounded, red and/or white excrescences } \\
\text { Exophytic - irregular blunt or sharp projections }\end{array}$ & $\begin{array}{l}\text { Clubbed nodular and } \\
\text { ulcerative together }\end{array}$ \\
\hline $\begin{array}{l}\text { Schepman }[16] \\
\quad(1995)\end{array}$ & $\begin{array}{l}\text { Size (L), Site (S), } \\
\text { Clinical aspect } \\
\text { (C) and Histo- } \\
\text { pathological } \\
\text { features (P) }\end{array}$ & $\begin{array}{l}\text { Provisional (Clinical) Diagnosis } \\
\text { 1st symbol: L = Extent of leukoplakia } \\
\text { L0 = No evidence of lesion; L1= Lesion }<2 \mathrm{~cm} \text {; L2 = Lesion }>2 \mathrm{~cm} \text { to } 4 \mathrm{~cm} \text {; L3 = Lesion >4 } \\
\text { cm; Lx = Not specified } \\
\text { 2nd symbol: S= Site of leukoplakia } \\
\text { S1 = All oral sites except for floor of mouth \& tongue } \\
\text { (Low Risk Sites); S2 = Floor of mouth and / or the tongue (High Risk Sites); Sx = Not } \\
\text { specified } \\
\text { 3rd symbol: C = clinical Aspect } \\
\text { C1= Homogenous; C2= Non-homogenous;C3= Not specified } \\
\text { Definitive (Histopathological) diagnosis } \\
\text { 4th symbol: P = Histopathological features } \\
\text { P1 = No dysplasia; P2 = Mild dysplasia; P3 = Moderate dysplasia; P4 = Severe dysplasia; } \\
\text { Px = Not specified } \\
\text { Proposal for staging system for Oral leukoplakia } \\
\text { Stage I = Any L, S1, C1, P1 or P2 } \\
\text { Stage II = Any L, S1, C2, P1 or P2 } \\
\quad \text { Any L, S2, C2, P1 or P2 } \\
\text { Stage III = Any L, S2, C2, P1 or P2 } \\
\text { Stage IV = Any L, any S, any C, P3 or P4 }\end{array}$ & $\begin{array}{l}\text { * gave detailed } \\
\text { description in terms of } \\
\text { size, site and clinical } \\
\text { aspect like TNM staging } \\
\text { * It was time consuming } \\
\text { to use }\end{array}$ \\
\hline $\begin{array}{l}\text { Waal et al. [17] } \\
\quad(2000)\end{array}$ & $\begin{array}{l}\text { Size \& } \\
\text { pathology of } \\
\text { leukoplakia, } \\
\text { focusing on } \\
\text { absence or } \\
\text { presence of } \\
\text { epithelial } \\
\text { dysplasia. }\end{array}$ & $\begin{array}{l}\text { Symbol: } \mathrm{L}=\text { Size of leukoplakia } \\
\mathrm{L} 1=\text { Size of single or multiple leukoplakia together }<2 \mathrm{~cm} \text {; } \mathrm{L} 2=\text { Size of single or multiple } \\
\text { leukoplakia together } 2-4 \mathrm{~cm} \text {; } \mathrm{L}=\text { Size of single or multiple leukoplakia together }>4 \mathrm{~cm} \text {; } \\
\text { LX = Size not specified. } \\
\text { Symbol: } \mathrm{P}=\text { Pathology } \\
\text { P0= No epithelial dysplasia (includes no or perhaps mild epithelial dysplasia); P1= } \\
\text { Distinct epithelial dysplasia (includes mild to moderate to possibly severe epithelial } \\
\text { dysplasia.); PX= Absence of epithelial dysplasia is not specified in pathology report. } \\
\text { Staging system proposed was- } \\
\text { Stage I = L1P0 } \\
\text { Stage II =L2P0 } \\
\text { Stage III = L3P0 or L1L2P1 } \\
\text { Stage IV = L3P1 }\end{array}$ & $\begin{array}{l}\text { * It was a simplified } \\
\text { version of classification } \\
\text { proposed by Schepman } \\
* \text { It was less time } \\
\text { consuming as compared } \\
\text { to classification given by } \\
\text { Schepman }\end{array}$ \\
\hline
\end{tabular}

Table 3: Histopathologic grading systems associated with leukoplakia.

\begin{tabular}{|c|c|c|c|}
\hline AUTHOR & HIGHLIGHTS & NEW POINTS & SHORTCOMINGS \\
\hline $\begin{array}{l}\text { Smith and Pindborg } \\
\text { system [19] (1969) }\end{array}$ & $\begin{array}{l}\text { *Attempted to standardize grading of } \\
\text { dysplasia by photographic method } \\
\text { * } 13 \text { histological features were standardized } \\
\text { by a set of photographs } \\
\text { *Each feature was graded as absent, slight or } \\
\text { marked } \\
\text { *Dysplasia was graded as absent, mild, } \\
\text { moderate and severe }\end{array}$ & $\begin{array}{l}\text { Produces an assessment of dysplasia on } \\
\text { an ordinal scale which facilitates statistical } \\
\text { analysis }\end{array}$ & $\begin{array}{l}\text { * Numerical scores for individual } \\
\text { features have been allocated } \\
\text { subjectively by the authors and } \\
\text { are not evidence-based } \\
\text { *It suffers interobserver and } \\
\text { intraobserver variability } \\
\text { * Time-consuming to use }\end{array}$ \\
\hline $\begin{array}{c}\text { Banoczy and Sciba } \\
{[20]} \\
(1976)\end{array}$ & $\begin{array}{l}\text { * Epithelial dysplasia was diagnosed using } 9 \\
\text { dysplastic features suggested by Mehta et al } \\
\text { (1971). } \\
\text { * Graded epithelial dysplasia as mild, } \\
\text { moderate and severe }\end{array}$ & $\begin{array}{l}\text { Dysplasia was graded on basis of number of } \\
\text { dysplastic features. } \\
\text { Mild = } 2 \text { dysplastic features. } \\
\text { Moderate }=2 \text { to } 4 \\
\text { Severe }=5 \text { or more }\end{array}$ & $\begin{array}{l}\text { * Was based on subjective } \\
\text { interpretation of the features } \\
\text { * Didn't take into account } \\
\text { which factor was important } \\
\text { in determining the malignant } \\
\text { potential }\end{array}$ \\
\hline
\end{tabular}




\begin{tabular}{|c|c|c|c|}
\hline W.H.O.[21] (1978) & $\begin{array}{l}\text { * Listed } 12 \text { histologic features that } \\
\text { characterized } \\
\text { epithelial dysplasia } \\
\text { * Dysplasia was again graded as mild, } \\
\text { moderate and severe }\end{array}$ & $\begin{array}{l}\text { Grading was based on the thickness of } \\
\text { epithelium involved, nuclear abnormalities, } \\
\text { cell maturation and stratification and } \\
\text { abnormal mitosis. } \\
\text { Following new dysplastic features were } \\
\text { added: } \\
\text { 1. Drop shaped rete ridges } \\
\text { 2. Mitotic figures in superficial layers of } \\
\text { epithelium } \\
\text { 3. Enlarged nucleoli }\end{array}$ & $\begin{array}{l}\text { * It suffers interobserver and } \\
\text { intraobserver variability } \\
\text { * Didn't take into account } \\
\text { which factor was important } \\
\text { in determining the malignant } \\
\text { potential }\end{array}$ \\
\hline Kramer [22] (1980) & $\begin{array}{l}\text { *Listed } 14 \text { dysplastic features } \\
\text { *Epithelium was called dysplastic if it } \\
\text { showed presence of } 2 \text { or more of the } \\
\text { dysplastic features } \\
\text { *Dysplasia was graded as present or absent }\end{array}$ & $\begin{array}{l}\text { *Grading was based on the same criteria as } \\
\text { that of WHO (1978) } \\
\text { *Following new dysplastic features were } \\
\text { added: } \\
\text { 1.Cell crowding } \\
\text { 2.Abnormal mitosis }\end{array}$ & $\begin{array}{l}\text { * It suffers interobserver and } \\
\text { intraobserver variability } \\
\text { * Didn't take into account } \\
\text { which factor was important } \\
\text { in determining the malignant } \\
\text { potential }\end{array}$ \\
\hline $\begin{array}{l}\text { Burkhardt and } \\
\text { Maerkar [23-25] } \\
\text { (1981) }\end{array}$ & $\begin{array}{l}\text { Listed } 6 \text { histological and cytological } \\
\text { parameters, based on which diagnosis and } \\
\text { classification of epithelial dysplasia could be } \\
\text { made. Dysplasia was graded as low, medium, } \\
\text { high and Carcinoma in situ (CIS) }\end{array}$ & $\begin{array}{l}\text { *A new category i.e. CIS was introduced } \\
\text { * Introduced additional indicators of } \\
\text { dysplasia like increase in subepithelial } \\
\text { lymphocytes, plasma cells and } \\
\text { interepithelial cells (stroma reaction) and } \\
\text { presence of candida organisms. }\end{array}$ & \\
\hline $\begin{array}{l}\text { Lumermann H. et al. } \\
\text { [26] (1995) }\end{array}$ & $\begin{array}{l}\text { Considered basal cell hyperplasia, nuclear } \\
\text { enlargement and hyperchromaticity, drop } \\
\text { shaped rete pegs as 'minimal' criteria for } \\
\text { diagnosis of oral epithelial dysplasia. } \\
\text { Dysplasia was graded as mild, moderate, } \\
\text { severe, CIS, Verrucous hyperplasia with } \\
\text { dysplasia }\end{array}$ & $\begin{array}{l}\text { *Grading was based on thickness of } \\
\text { epithelium involved by minimal criteria of } \\
\text { diagnosis } \\
\text { *A new category i.e Verrucous hyperplasia } \\
\text { with dysplasia was introduced }\end{array}$ & $\begin{array}{l}\text { * The new category (verrucous } \\
\text { hyperplasia) creates confusion } \\
\text { during grading }\end{array}$ \\
\hline $\begin{array}{l}\text { Neville et al. [27] } \\
\text { (1995) }\end{array}$ & $\begin{array}{l}\text { Graded dysplasia as mild, moderate, severe, } \\
\text { CIS }\end{array}$ & & \\
\hline $\begin{array}{l}\text { Speight P M et al. [28] } \\
\qquad(1996)\end{array}$ & Graded dysplasia as mild, moderate, severe & $\begin{array}{l}\text { Considered the thickness (height) to which } \\
\text { the cellular and tissue changes may extend, } \\
\text { as important in grading dysplasia }\end{array}$ & $\begin{array}{l}\text { Warnakulasuria (2001) } \\
\text { commented that there was wide } \\
\text { variation in the thickness of the } \\
\text { covering epithelium in the oral } \\
\text { cavity, with much undulation } \\
\text { which lead to practical } \\
\text { difficulties in using this grading } \\
\text { system [29] }\end{array}$ \\
\hline $\begin{array}{l}\text { Kuffer and Lombardi } \\
\text { [30] (2002) }\end{array}$ & $\begin{array}{l}\text { *Proposed to dismember the classical } \\
\text { "oral precancerous lesions" into following } \\
\text { categories: } \\
\text { Risk lesions - which histologically do } \\
\text { not show dysplasia (eg. Simple tobacco } \\
\text { keratosis) } \\
\text { Precursors of SCC-lesions with dysplasia (i.e. } \\
\text { already engaged in the process of malignant } \\
\text { transformation (eg; tobacco keratosis with } \\
\text { dysplasia) }\end{array}$ & $\begin{array}{l}\text { Introduced the terms risk lesions and } \\
\text { precursors of SCC (squamous cell } \\
\text { carcinoma) }\end{array}$ & $\begin{array}{l}\text { *Using the term "risk lesion" for } \\
\text { lesions without dysplasia which } \\
\text { have a no risk of } \\
\text { Malignant transformation (eg. } \\
\text { Frictional keratosis) } \\
\text { is inappropriate. } \\
\text { *All dysplasias do not progress } \\
\text { to SCC, hence calling all } \\
\text { dysplasias as precursors of SCC } \\
\text { is not justified. }\end{array}$ \\
\hline $\begin{array}{l}\text { Brothwell D J et al. } \\
\text { [31] (2003) }\end{array}$ & $\begin{array}{l}\text { Graded epithelial dysplastic lesions } \\
\text { according to } 5 \text { point scale; } \\
0=\text { No dysplasia; } 1 \text { = Mild; } 2 \text { = Moderate; } 3= \\
\text { Severe; } 4 \text { = CIS }\end{array}$ & $\begin{array}{l}\text { Using this system, and statistical analysis, } \\
\text { authors proved that intra and interobserver } \\
\text { agreement in grading the dysplastic lesions } \\
\text { were consistent }\end{array}$ & \\
\hline Ljubljana [32] (2003) & $\begin{array}{l}\text { *Developed to cater for the special clinical } \\
\text { and histological problems of laryngeal } \\
\text { abnormalities. } \\
\text { *Terms used were- Simple hyperplasia, } \\
\text { abnormal hyperplasia, Atypical (risky) } \\
\text { hyperplasia, CIS }\end{array}$ & & $\begin{array}{l}\text { Still doubtful if this system can } \\
\text { be used satisfactorily for oral } \\
\text { and oropharyngeal precursor } \\
\text { lesions }\end{array}$ \\
\hline
\end{tabular}




\begin{tabular}{|c|c|c|}
\hline $\begin{array}{l}\text { WHO [33] } \\
(2005)\end{array}$ & $\begin{array}{l}{ }^{*} \text { Grading was based on cytological and } \\
\text { architectural dysplastic features listed by } \\
\text { WHO in } 2005 . \\
{ }^{*} \text { Dysplasia was graded as - Squamous } \\
\text { hyperplasia, mild, moderate, severe } \\
\text { dysplasia, CIS }\end{array}$ & $\begin{array}{l}\text { Squamous hyperplasia introduced as a new } \\
\text { category }\end{array}$ \\
\hline $\begin{array}{l}\text { Binary system [34] } \\
\text { (2005) proposed by } \\
\text { Omar Kujan et al. }\end{array}$ & $\begin{array}{l}\text { * Considering the problems in making } \\
\text { reliable distinctions between the different } \\
\text { grades, } 4 \text { grades were collapsed to } 2 \text {. } \\
\text { *Categories were: High risk lesions (with } \\
\text { potential susceptibility for malignant } \\
\text { transformation) and Low risk lesions ( no } \\
\text { potential for malignant transformation) }\end{array}$ & $\begin{array}{l}\text { *With the reduction in number of grades, } \\
\text { interobserver variability was expected to } \\
\text { decrease }\end{array}$ \\
\hline
\end{tabular}

\section{Conclusion}

Leukoplakia has been one of the most debatable topics amongst the pathologists owing to its ever changing definitions, terminologies, classifications and interobserver and intraobserver variabilities. Till date, no definition, terminology, classification or grading has been declared to be ideal, and this leads to lack of uniformity in their usage by pathologists around the world. The knowledge and understanding of all the terminologies and classifications along with their shortcomings will provide a better insight for evaluating their appropriateness and comprehensiveness.

\section{References}

1. Jenson AB, Lancaster WD, Kurman RJ. Uterine cervix. In: Henson DE Albores-Saavedra J, editors. The Pathology of Incipient Neoplasia. Philadelphia: Saunders; 1986.

2. Prinz H. Leukoplakia oris-A clinical study. Dent Cosmos. 1928; 70: 663-72.

3. Schwimmer E. Die idiopathischen Schleimhaut plaques der Mundhöhle (Leukoplakia buccalis). Arch Dermat Syph. 1877; 9: 570-611.

4. Silverman S Jr, Gorsky M, Kaugars GE. Leukoplakia, dysplasia and malignant transformation. Oral Surg Oral Med Oral Pathol Oral Radiol Endod. 1996; 82(2): 117.

5. Pindborg JJ, Renstrup G, Poulsen HE, Silverman S. Studies in oral leukoplakias. V. Clinical and histologic signs of malignancy. Acta Odontol Scand. 1963; 21: 407-14.

6. Prabhu SR, Wilson DF, Daftary DK, Johnson NW. Oral diseases in the tropics. India: Oxford University Press; 1993.

7. Shafer, Hine, Levy. Text book of Oral Pathology. 6th ed. New Delhi Elsevier; 2009.

8. Mehta FS, Hamner JE. Tobacco related oral mucosal lesions and conditions in India. India: Basic Dental Research Unit; 1993.

9. Pindborg JJ, Roed-Peterson B, Renstrup G. Role of smoking in floor of the mouth leukoplakias. J Oral Pathol. 1972; 1(1): 22-9.

10. Kramer IR, Lucas RB, Pindborg JJ, Sobin LH. Definition of leukoplakia and related lesions: an aid to studies on oral precancer. Oral Surg Oral Med Oral Pathol. 1978; 46(4): 518-39.

11. Axell T, Holmstrup P, Kramer IRH, Pindborg JJ, Shear M. International seminar on oral leukoplakia and associated lesions related to tobacco habits. Community Dent Oral Epidemiol. 1984; 12(3): 145-154.

12. Bouquot JE. Oral leukoplakia and erythroplakia: a review and update. Pract Periodontics Aesthet Dent. 1994; 6(6): 9-17.
13. Axell T, Pindborg JJ, Smith CJ, van der Waal I. Oral white lesions with special reference to precancerous and tobacco- related lesions: conclusions of an international symposium held in Uppsala, Sweden, May 18-21 1994. International Collaborative Group on Oral White Lesions. J Oral Pathol Med. 1996; 25(2): 49-54.

14. Warnakulasuriya S, Johnson NW, van der Waal I. Nomenclature and classification of potentially malignant disorders of the oral mucosa. J Oral Pathol Med. 2007; 36(10): 575-80.

15. Mehta FS, Pindborg JJ, Hamner JE. Oral cancer and precancerous conditions in India. Copenhagen: Munksgaard; 1971.

16. Amagasa T, Michi K, Saito K, Ueno T. Clinical classification of oral leukoplakia. Japan J Oral Surg. 1977; 23: 89-96.

17. Schepman KP, van der Waal I. A proposal for a classification and staging system for oral leukoplakia: a preliminary study. Eur J Cancer B Oral Oncol. 1995; 31B(6): 396-98.

18. van der Waal I, Schepman KP, van der Meij EH. A modified classification and staging system for oral leukoplakia. Oral Oncol. 2000; 36(3): 26466.

19. Smith CJ, Pindborg JJ. Histological grading of oral epithelial atypia by the use of photographic standards. Hamburgers Bogtrykkeri, Copenhagen: C. Hamburgers Bogtrykkeri A/S; 1969.

20. Banoczy J, Csiba A. Occurrence of epithelial dysplasia in oral leukoplakia. Analysis and follow-up study of 12 cases. Oral Surg Oral Med Oral Pathol. 1976; 42(6): 766-74.

21. Kramer IR, Lucas RB, el-Labban N, Lister L. A computer-aided study on the tissue changes in oral keratoses and lichen planus, and an analysis of case groupings by subjective and objective criteria. $\mathrm{Br} \mathrm{J}$ Cancer. 1970; 24(3): 407-26.

22. Mackenzie IC, Dabelsteen E, Squire CA. Oral premalignancy. Iowa City: University of Iowa press; 1980.

23. Shklar. Oral Cancer. Tokyo: WB Saunders Company; 1984.

24. Soames JV, Southem JC. Oral Pathology. New York: Oxford Medical Publications; 1998.

25.Gnepp DR. Diagnostic Surgical Pathology of the Head and Neck. Philadelphia: WB Saunders Company; 2001.

26. Lumerman H, Freedman P, Kerpel S. Oral epithelial dysplasia and the development of invasive squamous cell carcinoma. Oral Surg Oral Med Oral Pathol Oral Radiol Endod. 1995; 79 (3): 321-29.

27. Neville BW, Damm DD, Allen CM. Oral and maxillofacial pathology. 3rd ed. London: WB Saunders Company; 2001.

28. Speight PM. Update on oral epithelial dysplasia and progression to cancer. Head Neck Pathol. 2007; 1(1): 61-6. 
29. Warnakulasuriya S. Histological grading of oral epithelial dysplasia: revisited. J Pathol. 2001; 194(3):294-97.

30. Kuffer J, Lombardi S. Reconsideration oral risk lesions. Oral Dis. 2002 38: 302-7.

31. Brothwell DJ, Lewis DW, Bradley G, Leong I, Jordan RC, Mock D et al. Observer agreement in the grading of oral epithelial dysplasia. Community Dent Oral Epidemiol. 2003; 31(4): 300-5.

32.Zerdoner D. The Ljubljana classification - its application to grading oral epithelial hyperplasia. J Craniomaxillofac Surg. 2003; 31(2): 75-9.

33. Barnes L, Eveson JW, Reichart P, Sidransky D. World Health Organization Classification of Tumors. Pathology and genetics of head and neck tumors. Lyon: IARC Press; 2005.

34. Kujan 0, Oliver RJ, Khattab A, Roberts SA, Thakker N, Sloan P. Evaluation of a new binary system of grading oral epithelial dysplasia for prediction of malignant transformation. Oral Oncol. 2006; 42(10): 987-93. 